\title{
Research on Building Curriculum System of Entrepreneurship Education for College Students in China
}

\author{
Yue Hao \\ College of Business Administration, Jilin Engineering Normal University, Changchun City, China \\ 18792044@qq.com
}

Keywords: Entrepreneurship education; Curriculum system; College students; Building; Research

\begin{abstract}
The implementation of entrepreneurship education is the requirement of higher education in China, the reform of higher education must be achieved through the construction of curriculum system. Based on this, we analyze the problems existing in the current entrepreneurship education course construction in our country, expound the goals of entrepreneurship education courses in colleges and universities, from four aspects, the pioneering education systematic integrated curriculum, simulation training course, business practices and practical, to construct the curriculum system of entrepreneurship education in colleges and universities, entrepreneurship education curriculum system in universities .Finally we set up the safeguard mechanism.
\end{abstract}

\section{Introduction}

UNESCO published "higher education in the 21st century: prospects and action declaration of the world" in the international symposium held in Beijing in 1998. In this publisher UNESCO emphasis "We must develop the students' entrepreneurial skills and entrepreneurial spirit as the basic goal of higher education" [1]. In many developed countries have carried out the entrepreneurship education in different extent to promote students entrepreneurial ability of exploration, and achieved obvious effect. In The United States more than 1100 colleges and universities set up courses in the field of entrepreneurship, many colleges and universities also have business professional, entrepreneurship education has become an important part of the American college of education. Entrepreneurship education in China starts late, entrepreneurship education curriculum is still in the education pilot stage [2]. In 1998, Tsinghua University for MBA opened in school of economics and management, take the lead in innovation and entrepreneurship management direction, also for the entire school undergraduate courses in the high-tech entrepreneurial management. The current of the typical entrepreneurship education courses in colleges and universities are mainly "business management" "entrepreneurship" "business plan", etc. Overall, the course construction of the entrepreneurship education of our country has many problems.

\section{The Problem of Universities' Entrepreneurship Education Curriculum Construction in China}

The Contents of Curriculum Are Lack of Scientific Nature. The common practice of current colleges and universities to carry out the entrepreneurship education is setting up compulsory or elective courses, some universities also through entrepreneurship training for entrepreneurship education. In curriculum design, the selection of the teaching methods always use the traditional way, most cultivation of student's entrepreneurial ability and form is not practical, can't meet the needs of entrepreneurial talent training [3]. Entrepreneurship course content such as the construction of the pioneering consciousness cultivation, knowledge, entrepreneurial psychological quality education, the cultivation of entrepreneurship is relatively defective, entrepreneurship education course has not yet make scientific planning.

The System Construction of Teaching Material Is Lack of Authority. Foreign countries have developed some popular teaching material, formed a relatively mature teaching means and teaching evaluation standard. Babson college and London business school jointly issued the GEM report, in 2001 
the United States more than 1500 four-year colleges and universities provides entrepreneurship, it can be say that almost all have been opened at the American university ranking university entrepreneurship now. In our country, even though universities have entrepreneurship education courses, in the choice of teaching material also has significant limitations [4].

The Teaching Faculties Are not Professional Enough. Entrepreneurship education for the teachers' requirements are relatively high, not only asked them to have a certain theoretical knowledge, but also need to have certain experience. In foreign countries, most of the entrepreneurship education curriculum teaching teachers have business or investment experience, familiar with the operation of the enterprise. At present our country for entrepreneurship education course teachers are experts, but real entrepreneurial experience, rich practical experience and professional discipline leaders are defective.

The Consistency Is Lack between Theory and Practice. Influenced by the traditional education mode, entrepreneurship education in our country education theoretical basis, and neglect the cultivation of students' practical ability, trending to lack of talents with social good entrepreneurial skills, distinctive personality and creative thought. Entrepreneurship education of colleges and universities is mainly confined to the pioneer park, incubation centers, limited by funding, conditions, professional, theoretical study for students can not be effectively applied in business practice.

The Activities of Entrepreneurship Education Is Lack of Diversity. Some think the purpose of entrepreneurship education in colleges and universities is to let students to participate in a contest, or teach students to start a business or company, and vigorous land to carry out all kinds of business competition [5]. Misled by cognitive, most college students just for game, such as student's credentials the exercise, social practice and scientific research project, corporate trainee entrepreneurship practice activities, such as less, cause the students to participate in the process of entrepreneurship of entrepreneurial projects is less, unable to effectively gain experience.

\section{The Curriculum's Objectives of Universities' Entrepreneurship Education in China}

Entrepreneurship education curriculum is a comprehensive system, which needs to set up the course of interdisciplinary. So to promote entrepreneurship education curriculum system construction in colleges and universities, make innovation, entrepreneurial ideas into their teaching. Entrepreneurship education in colleges and universities curriculum goals should be identified as: training students the basic quality and innovative entrepreneurial personality, make education has the basic sense of entrepreneurship, business entrepreneurship psychological quality, knowledge structure, entrepreneurship, according to a few real student entrepreneurs, help them to their own businesses.

Set up the Ideas of Entrepreneurship. It not only cultivates the students' entrepreneurial self-awareness, but also cultivates the students' entrepreneurial social consciousness. Let the students to form the social sense of responsibility, set up the hard working thought, be brave in exploitation and keep innovating [6].

Develop Entrepreneurial Psychological Quality. Universities should according to the characteristics of students' personality and to cultivate the students' independence, courage, tenacity, flexibility, extraversion, cooperative venture psychological quality, take the strong willpower and positive attitude as a starting point to develop entrepreneurial psychological quality and emphasis.

Form the Entrepreneurial Knowledge Structure. The key is to make students form a reasonable and orderly knowledge structure, including professional knowledge, management knowledge and comprehensive knowledge, help students establish the concept of initiative learning and lifelong learning, and be good at expanding knowledge and flexible use of various knowledge solution actual problem ability.

Improve the Ability of Entrepreneurship. In entrepreneurial practice, entrepreneurship is activity factor, efficiency, and the results of direct operation, through the entrepreneurship education curriculum, mainly develop the students' professional skills, management ability and crisis control ability, experience for students to achieve their own businesses [7]. 
Realize The Truth of Businesses. Carrying out entrepreneurial skills practice, providing financial supports, technical supports for the minority students can help them start a business, make the job self-invention and realize their self-worth.

\section{The Conception of Setting up the Curriculum System of College Students' Entrepreneurship Education}

Science curriculum is the key of the business-pioneering education. Entrepreneurship education course is the form of entrepreneurship education and entrepreneurial education platform and the backing, is also one of the most important method to achieve teaching purpose [8]. The setting of entrepreneurship must be combined with the main characteristics of college students' entrepreneurship education and students' real needs. Therefore, before the courses built, we should have a general idea about the ability students had.

Table 1 The construction of College students' entrepreneurship education curriculum system

\begin{tabular}{|l|l|l|}
\hline Items & Contents & Objects \\
\hline Basic contents & $\begin{array}{l}\text { Courses, social investigation, business simulation } \\
\text { training, academic activities, to participate in various } \\
\text { competitions }\end{array}$ & $\begin{array}{l}\text { Comprehensive } \\
\text { training from theory } \\
\text { to practice }\end{array}$ \\
\hline $\begin{array}{l}\text { Basic } \\
\text { requirements }\end{array}$ & $\begin{array}{l}\text { Self-study ability, ability to capture market } \\
\text { opportunities, resisting setback ability, practice ability }\end{array}$ & $\begin{array}{l}\text { Entrepreneurial } \\
\text { ability training }\end{array}$ \\
\hline $\begin{array}{l}\text { Organizational } \\
\text { guarantee }\end{array}$ & $\begin{array}{l}\text { Participate business base, funds, rules and } \\
\text { regulations, equipment and facilities }\end{array}$ & $\begin{array}{l}\text { The entrepreneurial } \\
\text { practice }\end{array}$ \\
\hline
\end{tabular}

Training College Students' Entrepreneurial Quality and Innovation Consciousness by Comprehensive Courses. Comprehensive course mainly includes the basic theory courses, subject courses and elective courses, to let the students have a more comprehensive and systematic study and understanding. Basic theory course focused on relying on their professional, penetrating entrepreneurship education curriculum. This not only uses the lass resources, expanding the application field of the subject teaching, but also optimize the teaching content, broadening the students' knowledge. Subject the main course is designed for college students' entrepreneurship, include the pioneering consciousness, psychology class, entrepreneurs quality courses, entrepreneurial social common knowledge [9]. Subject courses are according to the student's own interest, hobbies, special skill, etc to selectively study, in order to satisfy different development.

Training Students' Ability in the Courses of Business Simulation. Business simulation training course can expand students' entrepreneurial knowledge and entrepreneurial background, rich business knowledge, accumulation of experience. Such as open enterprise competition, ERP sand table simulation training, through lead students into a simulated competitive industries, several competing simulation company established by a group students, with the help of online teaching AIDS, or sand table simulation company practice simulation of enterprise operation and management and market competition. Through simulation training practice, students can understand deeply the competition of enterprise operation, make the original theory knowledge and management practice to better achieve mastery through a comprehensive study, for the operation and management have very good guiding significance in the future.

Training Comprehensive Ability and Entrepreneurial Psychological Quality through Business Practice Courses. Entrepreneurship practice course mainly includes: real training, mainly rely on colleges , universities and local, enterprise and college students' social practice base, to build the practical training base to make the students into the enterprise, feel the enterprise management operation; To participate in the activities of science and technology and social projects, such as participation in college 
students' innovation fund to support projects, participate in the teacher's scientific research projects, projects independently selected by the students on the basis of personal interest, helps to cultivate the students' psychological quality, improve the comprehensive ability and creative consciousness; Participate in the "challenge cup" business plan competition, lets the student for a business or considering setting up a small business to write business plan, the final project defense [10]. Students not only to active learning and integrated application of business plan involves various aspects knowledge, investigate the reality the relevant enterprises and market, but also in completing the task team cooperation and division of labor, perceptual knowledge and practical experience to gain business.

Strengthening the Guidance of Entrepreneurial Practice Projects, and Providing Intellectual Support for Entrepreneurial Projects to the Market. Many college students in colleges and universities entrepreneurship education goal is to establish enterprises with a certain scale company, or absorb huge risk investment. But I learned in the study of Wenzhou University, the school established the "studio" entrepreneurship, is characterized by small size, less investment, quick effect, small risk, flexible operation. This venture studio neither huge risk investment, also don't need a lot of costs, pay attention to the accumulation of from small to large, emphasized in practice to cultivate entrepreneurial awareness, promote entrepreneurship ability. Some universities can set up a business when conditions are ripe project "incubator", for the minority has the core technology and good market prospects of start-ups offer certain help, the project "rotary launched", to participate in the national, provincial entrepreneurship competition, should also be on the way of business for a ride, for entrepreneurial projects provide material assistance and intellectual support to the market [11].

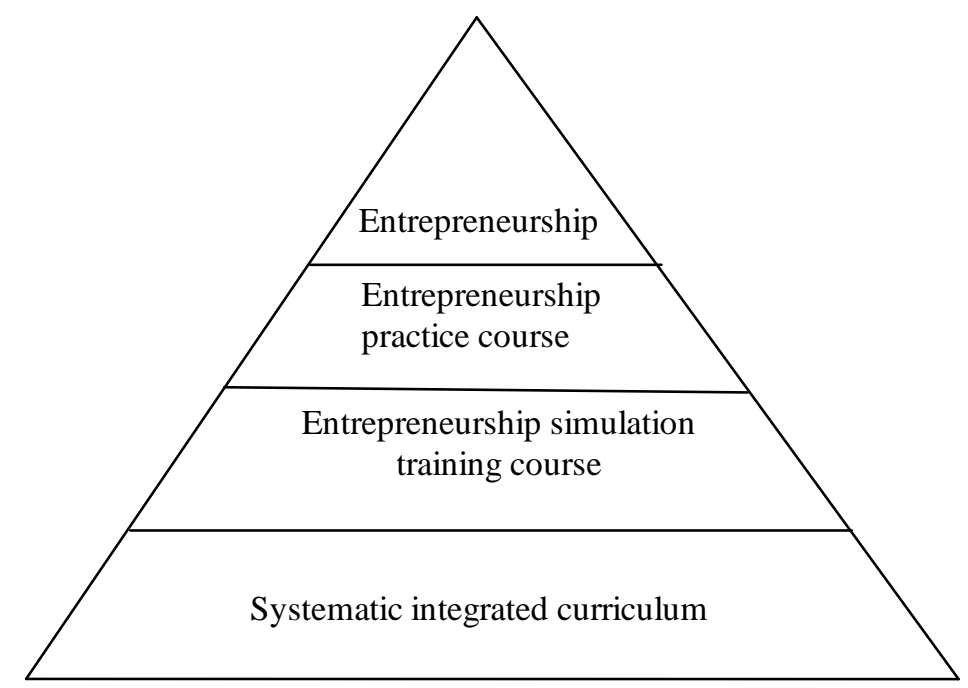

Figure 1. Entrepreneurship education curriculum system

The basic idea of entrepreneurship education curriculum is: junior systematic comprehensive course, entrepreneurship training courses, mainly for the accumulation of business knowledge and the cultivation of the pioneering consciousness and quality; Senior courses in business practice, entrepreneurial projects, support the college students' self-employment. Systematic integrated curriculum is a base layer, business simulation training and entrepreneurship practice course is a comprehensive layer, business of actual combat, self-employment is to improve the layer, so to form a perfect curriculum system.

To strengthen entrepreneurship education, and continuously explore college students' entrepreneurial education mode and approach, is the first job education workers should do. The building of entrepreneurship education course system, carrying out the basic purpose of entrepreneurship education, is the basic way to foster more entrepreneurship consciousness and more entrepreneurial talent. Universities should be based on the school characteristics, constructs the course system of entrepreneurship education, train more innovative talents for the development of the society. 


\section{References}

[1] K.H. Xiao: Education and Vocation, Vol. 45 (2012) No.23, p.120-122.

[2] L. Jiao and Y. Wang: Journal of Liaoning Educational Administration Institute, Vol. 29 (2015) No.2, p.46-49.

[3] E.S. Zhang and Q.C. Li: Journal of Shandong Youth University of Political Science, Vol. 17 (2015) No.2, p.73-77.

[4] X.H. Xia: Journal of Jixi University, Vol. 14 (2014) No.6, p.4-6.

[5] S.H. Zhang, X.H. Chen and Y.H. Lu: Journal of Jinling Institute of Technology (Social Science), Vol. 14 (2012) No.4, p.6-10.

[6] B. Ding, S.Y. Ye and M. Pu: Journal of Heilongjiang College of Education, Vol. 19 (2012) No.5, p.10-11.

[7] B.F. Niu: Henan Education, Vol. 7 (2011) No.12, p.29-30.

[8] L.Y. Ren and Z.X. Yang: Education Research Monthly, Vol. 27 (2010) No.11, p.17-20.

[9] B.C. Liu: China Higher Education, Vol. 31 (2012) No.12, p.12-15.

[10] A.S. Thomas and S.L. Mueller: Journal of International Business Studies, Vol. 31 (2000) No.2, p.287-301.

[11] X.W. Kunkel: The Impact of Strategy and Industry Structure on New Venture Performance (Ph.D., University of Georgia, America 1991), p.462-468. 